\title{
THREE NEW TETRAALKYLAMMONIUM BROMOCHROMATES, NR 4 [CRO 3 BR], (R= ET, HEX, HEP): MILD AND EFFICIENT REAGENTS FOR OXIDATION OF PRIMARY AND SECONDARY ALCOHOLS
}

\author{
SHAHRIARE GHAMMAMYI,2* KHEYROLLAH MEHRANI ${ }^{1}$ HAMID AFRAND ${ }^{I}$, ZAHRA JAVANSHIR ${ }^{l}$, \\ GHOLAMREZA REZAEIBEHBAHANI', ALI MOGHIMI ${ }^{3}$ AND ZAHRA SHOKRI AGHBOLAGH ${ }^{2}$
}

\author{
1. Department of Chemistry, Faculty of Science, Islamic Azad University, Ardebil Branch, Ardebil, Iran \\ 2. Department of Chemistry, Faculty of Science, Imam Khomeini International University, Qazvin, Iran \\ 3. Department of Chemistry Islamic Azad University Varamin Branch, Varamin, Iran
}

(Received: April 13, 2009 - Accepted: May 19, 2009)

\begin{abstract}
Tetraethylammonium Bromochromate, TEABC, Tetrahexylammonium Bromochromate, THexABC and Tetraheptylammonium Bromochromate, THepABC are new reagents used for almost quantitative conversion of alcohols into the corresponding aldehydes and ketones. These tetraalkylammonium bromochromate reagents are easily synthesized by the reaction of relative tetraalkylammonium bromide with a solution of $\mathrm{CrO}_{3}$ in a 1:1 mole ratio. These reagents are versatile agents for the effective and nearly quantitative oxidation of organic substrates, in particular for alcohols, under mild and acid-free conditions.
\end{abstract}

Keywords: Chromium(VI), Tetraethylammonium Bromotrioxochromate, Tetrahexylammonium Bromotrioxochromate, Tetrahepthylammonium Bromotrioxochromate, Oxidation, Organic substrates, Alcohols.

\section{INTRODUCTION}

Chromium(VI) compounds are widely used as oxidation agents. ${ }^{1}$ Watersoluble potassium and sodium dichromates with strong acids were used as oxidants and in most cases, the products were non-specific. The first attempt to make a mild reagent of substituted chromates was reported by Sarett and co-workers, who used pyridine to form a salt with $\mathrm{CrO}_{3}$, in order to oxidize some steroidal alcohols. ${ }^{2}$ This reagent was subsequently used by various workers without analyzing the structure of the oxidant. ${ }^{3}$ Corey, in his novel attempt to establish pyridinium chlorochromate ${ }^{4}$ as a versatile oxidant, revisited Sarett's reagent and discovered it to be pyridinium dichromate. ${ }^{5}$ Significant improvements are achieved in the development of new $\mathrm{Cr}(\mathrm{VI})$ based oxidizing agents, such as: the Collins reagent, ${ }^{6}$ caffeinilium chlorochromate, ${ }^{7}$ pyridinium bromochromate, ${ }^{8}$ chromium trioxide-3,5dimethylpyrazole complex,${ }^{9}$ 2,2'-bipyridinium chlorochromate, ${ }^{10}$ quinolinium fluorochromate, ${ }^{11}$ quinolinium chlorochromate, ${ }^{12}$ 3,5-dimethylpyrazolium fluorochromate, ${ }^{13}$ pyridinium fluorochromate, ${ }^{14}$ propyltriphenylphosphonium bromochromate, ${ }^{15}$ tetramethylammonium fluorochromate(VI) $\left(\right.$ TMAFC) ${ }^{16}$ and tripropylammonium fluorochromate. ${ }^{17}$ These reagents may all be used for the oxidation of alcohols to corresponding aldehydes and ketones. Even though, numerous oxidants for oxidation of alcohols are already reported, the growing demand for new oxidants of alcohols made us carry out the synthesis of Tetraalkylammonium Bromochromates(VI).

\section{EXPERIMENTAL}

Tetraalkylammonium bromides and chromium trioxide were obtained from Fluka (Buchs, Switzerland). Melting points are measured on an Electrothermal 9100 apparatus and are uncorrected. Elemental analyses $(\mathrm{C}, \mathrm{H}$, and N) were performed using a Heraeus CHN-O-Rapid analyzer. Infrared spectra were recorded as $\mathrm{KBr}$ disks on a Shimadzu model 420 spectrophotometer. The UV/ Visible measurements were made on an Uvicon model 922 spectrophotometer. ${ }^{1} \mathrm{H}-\mathrm{NMR}$ and ${ }^{13} \mathrm{C}$-NMR spectra were measured on a BRUKER-DRX500 AVANCE instrument.

Synthesis of Tetraethylammonium Bromochromates

(VI), $\left.\left(\mathrm{C}_{2} \mathrm{H}_{5}\right) \mathrm{N} / \mathrm{CrO}_{3} \mathrm{Br}\right]$

To a solution of $1 \mathrm{~g} \mathrm{(10} \mathrm{mmol}) \mathrm{CrO}_{3}$ in $25 \mathrm{ml}$ acetonitrile, placed in a $100 \mathrm{ml}$ beaker, tetraethylammonium bromide $(2.10 \mathrm{~g}, 10 \mathrm{mmol})$ is added portion-wise with stirring. A reddish orange solid is separated and stored in the refrigerator. The solid was washed with hexane and dried under vacuum for $1 \mathrm{~h}: \mathrm{mp} 130^{\circ} \mathrm{C}$. $\mathrm{C}_{8} \mathrm{H}_{20} \mathrm{BrCrNO}_{3}$ : Calcd. $\% \mathrm{C}, 30.96 ; \% \mathrm{H}, 6.45 ; \% \mathrm{~N}, 4.51$. Found: $\% \mathrm{C}, 31.55$; $\% \mathrm{H}, 6.60 ; \% \mathrm{~N}, 4.68$. IR. (KBr): $895 \mathrm{~cm}^{-1} v_{1}\left(\mathrm{~A}_{1}\right)$ or $\mathrm{v}\left(\mathrm{CrO}_{3}\right)$ and $945 \mathrm{~cm}^{-1} \mathrm{v}_{4}(\mathrm{E})$ or $v\left(\mathrm{CrO}_{3}\right)$. UV/Visible ${ }^{13} \mathrm{C}-\mathrm{NMR}$ and ${ }^{1} \mathrm{H}$-NMR were all consistent with the TEABC structure. ${ }^{1} \mathrm{H}-\mathrm{NMR}\left(500 \mathrm{MHz}, \mathrm{CDCl}_{3}\right)$ d: $1.26\left(3 \mathrm{H}, t, \mathrm{CH}_{3}-\mathrm{CH}_{2}\right), 3.28$ $\left(2 \mathrm{H}, q,-\mathrm{CH}_{2}-\mathrm{N}\right) ;{ }^{13} \mathrm{C}-\mathrm{NMR}(125 \mathrm{MHz}$, DMSO- $d$ ) d: 6.92, 51.2, 51.33, 51.37. Electronic at $454 \mathrm{~nm}$, Corresponding to $1 \mathrm{a}_{2} \rightarrow 9 \mathrm{e}\left(\varepsilon=212 \mathrm{M}^{-1} \mathrm{~cm}^{-1}\right) ; 363 \mathrm{~nm}$ to
$8 \mathrm{e} \rightarrow 9 \mathrm{e}\left(\varepsilon=738 \mathrm{M}^{-1} \mathrm{~cm}^{-1}\right) ;$ and $263 \mathrm{~nm}$ to $12 \mathrm{a}_{1} \rightarrow 9 \mathrm{e}\left(\varepsilon=1882 \mathrm{M}^{-1} \mathrm{~cm}^{-1}\right)$.

Synthesis of Tetrahexylammonium Bromochromates (VI), $\left(\mathrm{C}_{6} \mathrm{H}_{13}\right)_{4} \mathrm{~N}\left[\mathrm{CrO}_{3} \mathrm{Br}\right]$

Chromium(VI) oxide $(1.0 \mathrm{~g} .10 \mathrm{mmol})$ was dissolved in dry acetonitrile $(25 \mathrm{ml})$ in a beaker and was added under stirring at $0{ }^{\circ} \mathrm{C}$. To the resultant clear orange solution, tetrahexylammonium bromide $(4.34 \mathrm{~g}, 10 \mathrm{mmol})$ was added under stirring at room temperature. Within $1 \mathrm{~h}$, a clear orange solution formed which upon refrigerating gave solid THexABC, which was isolated by filtration. The solid was washed with hexane, ether and dried under vacuum for 1 h. $\mathrm{mp} 90^{\circ} \mathrm{C} . \mathrm{C}_{24} \mathrm{H}_{52} \mathrm{BrCrNO}_{3}$ : Cacld. $\% \mathrm{C}, 53.93 ; \% \mathrm{H}, 9.73 ; \% \mathrm{~N}, 2.62$. Found: $\% \mathrm{C}, 54.98 ; \% \mathrm{H}, 9.89 ; \% \mathrm{~N}, 2.74$. IR $(\mathrm{KBr}): 901 \mathrm{~cm}^{-1} v_{1}\left(\mathrm{~A}_{1}\right)$ or $v\left(\mathrm{CrO}_{3}\right)$ and $948 \mathrm{~cm}^{-1} v_{4}(\mathrm{E})$ or $v\left(\mathrm{CrO}_{3}\right) \mathrm{cm}^{-1}$. UV/Visible and ${ }^{1} \mathrm{H}-\mathrm{NMR}$ were all consistent with the THexABC structure. ${ }^{1} \mathrm{H}-\mathrm{NMR}\left(500 \mathrm{MHz}, \mathrm{CDCl}_{3}\right)$ d: $0.9\left(3 \mathrm{H}, t,-\mathrm{CH}_{2}\right.$ $\left.\mathrm{CH}_{3}\right), 1.34\left(4 \mathrm{H}, m,-\left(\mathrm{CH}_{2}\right)_{2}-\mathrm{CH}_{3}\right), 1.42\left(2 \mathrm{H}, q,-\mathrm{CH}_{2}-\mathrm{CH}_{2}\right), 1.75\left(2 \mathrm{H}, q,-\mathrm{CH}_{2}-\right.$ $\left.\mathrm{CH}^{3}\right), 3.3\left(2 \mathrm{H}, q,-\mathrm{CH}_{2}-\mathrm{N}\right) ;{ }^{13} \mathrm{C}-\mathrm{NMR}(125 \mathrm{MHz}$, DMSO-d $)$ d: $13.2,22.4,22.9$, 26.7, 31.2, 59.97. Electronic at $453 \mathrm{~nm}$, corresponding to $1 \mathrm{a}_{2} \rightarrow 9 \mathrm{e}\left(\varepsilon=104 \mathrm{M}^{-1}\right.$ $\left.\mathrm{cm}^{-1}\right) ; 363 \mathrm{~nm}$ to $8 \mathrm{e} \rightarrow 9 \mathrm{e}\left(\varepsilon=1030 \mathrm{M}^{-1} \mathrm{~cm}^{-1}\right)$; and $262 \mathrm{~nm}$ to $12 \mathrm{a} \rightarrow 9 \mathrm{e}(\varepsilon=1394$ $\left.\mathrm{M}^{-1} \mathrm{~cm}^{-1}\right)$. UV/Visible, ${ }^{13} \mathrm{C}$ NMR and ${ }^{1} \mathrm{H}$ NMR were all consistent with the THexABC structure.

Synthesis of Tetraheptylammonium Bromochromates

$(V I)$, $\left(\mathrm{C}_{7} \mathrm{H}_{1}\right)_{4} \mathrm{~N}\left[\mathrm{CrO}_{3} \mathrm{Br}\right]$

Tetrahepthylammonium Bromochromate can be easily prepared in excellent yield from the reaction of $\mathrm{CrO}_{3}$ with tetrahepthylammonium Bromide in dry acetonitrile $(25 \mathrm{ml})$ in a beaker and was added under stirring at $0{ }^{\circ} \mathrm{C}$. To a solution of chromium trioxide $(1 \mathrm{~g}, 10 \mathrm{mmol})$ dry acetonitrile $(25 \mathrm{ml})$ was cooled to $0^{\circ} \mathrm{C}$ and a stoichiometric amount of Tetrahepthylammonium Bromide (4.87 g, $10 \mathrm{mmol}$ ) was added under stirring at room temperature. Within $1 \mathrm{~h}$, a clear orange solution formed which upon refrigerating gave solid THepABC, which was isolated by filtration. The solid was washed with hexane and petroleum ether and dried under vacuum for $1 \mathrm{~h} . \mathrm{mp} 76^{\circ} \mathrm{C} . \mathrm{C}_{28} \mathrm{H}_{60} \mathrm{BrCrNO}_{3}$ : Cacld. \%C, 56.94; \%H, 10.16; \%N, 2.37. Found: $\% \mathrm{C}, 58.12 ; \% \mathrm{H}, 10.31 ; \% \mathrm{~N}$, 2.46. IR. (KBr): $903 \mathrm{~cm}^{-1} v_{1}\left(\mathrm{~A}_{1}\right)$ or $\mathrm{v}\left(\mathrm{CrO}_{3}\right), 950 \mathrm{~cm}^{-1} \mathrm{v}_{4}(\mathrm{E})$ or $\mathrm{v}\left(\mathrm{CrO}_{3}\right)$. UV/ Visible was all consistent with the THepABC structure. ${ }^{1} \mathrm{H}-\mathrm{NMR}(500 \mathrm{MHz}$, $\left.\mathrm{CDCl}_{3}\right)$ d: $0.87\left(3 \mathrm{H}, t, \mathrm{CH}_{3}-\mathrm{CH}_{2}\right), 1.32\left(4 \mathrm{H}, m,-\left(\mathrm{CH}_{2}\right)_{2}-\mathrm{CH}_{3}\right), 1.43(4 \mathrm{H}, m$, $\left.-\left(\mathrm{CH}_{2}\right)_{2}-\mathrm{CH}_{2}\right), 1.68\left(2 \mathrm{H}, q,-\mathrm{CH}_{2}-\mathrm{CH}_{2}\right), 3.34\left(2 \mathrm{H}, q,-\mathrm{CH}_{2}-\mathrm{N}\right) ;{ }^{3} \mathrm{C}-\mathrm{NMR}(125$ MHz, DMSO- $d$ ) d: $14.01,22.36,22.48,26.33,28.82,31.50,59.20$. Electronic at $455 \mathrm{~nm}$, Corresponding to $1 \mathrm{a}_{2} \rightarrow 9 \mathrm{e}\left(\varepsilon=134 \mathrm{M}^{-1} \mathrm{~cm}^{-1}\right) ; 363 \mathrm{~nm}$ to $8 \mathrm{e} \rightarrow 9 \mathrm{e}(\varepsilon=$ $\left.661 \mathrm{M}^{-1} \mathrm{~cm}^{-1}\right)$; and $260 \mathrm{~nm}$ to $12 \mathrm{a}_{1} \rightarrow 9 \mathrm{e}\left(\varepsilon=1378 \mathrm{M}^{-1} \mathrm{~cm}^{-1}\right)$.

General procedure for oxidation:

To a stirred suspension of tetraalkylammonium boromochromate (1 $\mathrm{mmol}$ ) in dichloromethane (generally five $\mathrm{ml}$ ), a solution of the substrate in the minimum amount of dichloromethane was added dropwise, the molar ratio of substrate to the oxidant being 1:1 in. The mixture was refluxed for the 
time showed in the table. [The completion of the reaction is followed by UV/ Visible and TLC using ether/petroleum ether (60/40) as eluant]. The mixture was diluted with ether $(1: 1 \mathrm{vol} / \mathrm{vol})$ and filtered through a short column of silica gel to give a clear solution. The solution was evaporated and the residual product purified by distillation, recrystallization or column chromatography. The progress of the reactions was also monitored and checked by UV/Visible spectrophotometry. The amount of the oxidant during the reaction was measured spectrophotometrically at $363 \mathrm{~nm}$. A very small magnetic stirrer was designed at the cell (10 mm quartz cell) compartment just in the bottom of sample cell in the spectrophotometer to stir up the solution under study in cell. The reaction mixtures remained homogenous in the solvent system used.

\section{RESULTS AND DISCUSSION}

Organic chemists must often choose from hundreds of oxidizing agents and reaction conditions to perform a desired oxidation without affecting other functional groups present or causing side reactions. Although there are a broad variety of oxidants derived from $\mathrm{Cr}(\mathrm{VI})$ reported in literature to perform oxidation reactions the easy access to these tetraalkylammonium bromochromate reagents and the high yields reported in this paper are very satisfactory and show the new reagents as valuable additions to the existing oxidizing agents.

Tetraalkylammonium bromochromates in dichloromethane also oxidizes primary and secondary alcohols to, respectively, the corresponding aldehydes or ketones in high yields (Table I).

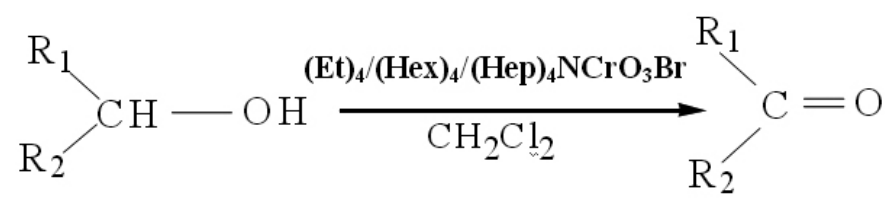

These tetraalkylammonium bromochromate reagents have also been used for oxidation of carbohydrates such as 1, 2: 5, 6 -Di-O-isopropylidine- $\alpha$ D-Glucofuranose to its relative ketosugar as pyridinium dichromate, but in different yields, and by use of the equimolar ratio of the reagents.

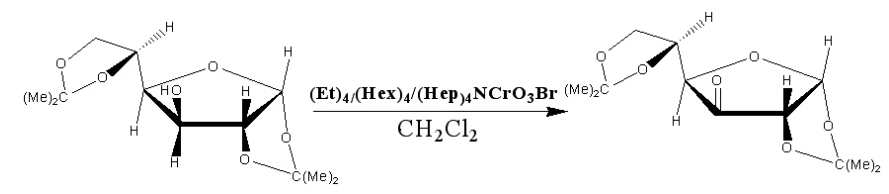

Further oxidation of aldehydes to their carboxylic acids was not observed. Under the same conditions alcohols are selectively oxidized to their corresponding carbonyl compounds.

Oxo complexes of transition metals are also as general purpose, stoichiometric oxidant in synthetic organic chemistry and a variety of reaction pathways including both atom-transfer and electron-transfer are involved. These reagents changed triphenylphosphine to triphenylphosphine oxide. This provides a clear-cut example of an oxygen transfer from reagent to alcohols or hydrogen transfer from the alcohols to the oxidants reaction involving tetraalkylammonium bromochromates and the result may also be useful in defining other related reactions. ${ }^{16-19}$

The nature of the solvent does not appear to be particularly critical. Hydrocarbons, benzene, ethers and chlorinated hydrocarbons are equally effective, the practical choice being oriented by the solubility of the products and the desired reaction temperature. The chromium(VI) contents easily determined iodometrically. The IR spectra of TEABC, THexABC and THepABC are similar to that of other Bromochromates. ${ }^{18}$

Because of the stability and solubility of TEABC, THexABC and $\mathrm{THepABC}$, reactions can be performed at room temperature and the separation of the products is facile. During the reactions, the color of the oxidants changes from orange to brown, providing visual means for ascertaining the progress of the oxidation.

These tetraalkylammonium bromochromate reagents appear to be stronger reagents than others; this could be due to theirs lower symmetry. It has been found also that these reagents have certain advantages over similar oxidizing agents in terms of amounts of oxidant and solvent required, and especially in the short reaction times required and in higher product yields. ${ }^{15-17}$

In addition this oxidant and the oxidation conditions can be used for the synthesis of highly functionalized molecules.

\section{ACKNOWLEDGEMENTS}

The authors would like to thank Dr. Mahjoub for valuable discussions.

\section{REFERENCES}

1. S. V. Ley and A. Madin, Organic Syntheses, Pergamon Press, Oxford. 1991.

2. G. I. Poos, G. E. Arth, R. E. Beyler and L. H. Sarett, J. Am. Chem. Soc., 75, 422, (1953).

3. (a) S. Bernstein and R. H. Lenhard, J. Am. Chem. Soc., 82, 3680, (1960). (b) R. K. Chawla and W. E. McGonigal, J. Org. Chem., 39, 3281, (1974). (c) J. C. Gilbert and K. R. Smith, J. Org. Chem., 41, 3883, (1976).

4. E. J. Corey and J. W. Suggs, Tetrahedron Lett., 31, 2647, (1975).

5. E. J. Corey and G. Schmidt, Tetrahedron Lett., 20, 399, (1979).

6. J. C. Collins, W.W. Hess and F.J. Frank, Tetrahedron Lett., 9, 3363, (1968).

7. F. Shirini, I. Mohammadpoor-Baltork, Z. Hejazi and P. Heravi, Bull. Korean Chem. Soc., 24, 517, (2003).

8. N. Narayanan and TR. Balasubramanian, Indian J. Chem., 25B, 228 (1986).

9. E. J. Corey and G. W. Fleet, J. Tetrahedron Lett., 45, 4499, (1973).

10. F. S. Guziec and F.A. Luzzio, Synthesis, 12, 691, (1980).

11. V. Murugesan and A. Pandurangan, Indian J. Chem., 31B, 377 (1992).

12. R. Srinivasan, C. V. Ramesh, W. Madhulatha and K. Balasubramanian, Indian J. Chem. Sec. B., 35B, 480, (1996).

13. U. Bora, M. K. Chaudhuri, D. Dey, D. Kalita, W. Kharmawphlang and G. C. Mandal, Tetrahedron, 57, 2445, (2001).

14. Bhattacharjee, M. N. Chaudhuri, M. K. Dasgupta, H. S. Roy, N. Synthesis, $588,(1982)$

15. S. Ghammamy, M. Rahnama Baghy, W. Wing-Tak, K. Mehrani, and Maleki, Transit. Metal Chem., 32, 257, (2007).

16. A. R. Mahjoub, S. Ghammami and M.Z. Kassaee, Tetrahedron Lett., 44, 4555, (2003).

17. S. Ghammamy and A. Hashemzadeh, Bull. Korean Chem. Soc., 25, 1277, (2004).

18. K. Nakamoto, Inorganic Compounds, Infrared and Raman Spectra of Inorganic and Coordination Compounds, Vol. 1. Part II, Third Edition, Wiley, New York, 1978, p. 140.

19. S. Ghammamy and M. Mazareey, J. Serb. Chem. Soc., 70, 687, (2005). 


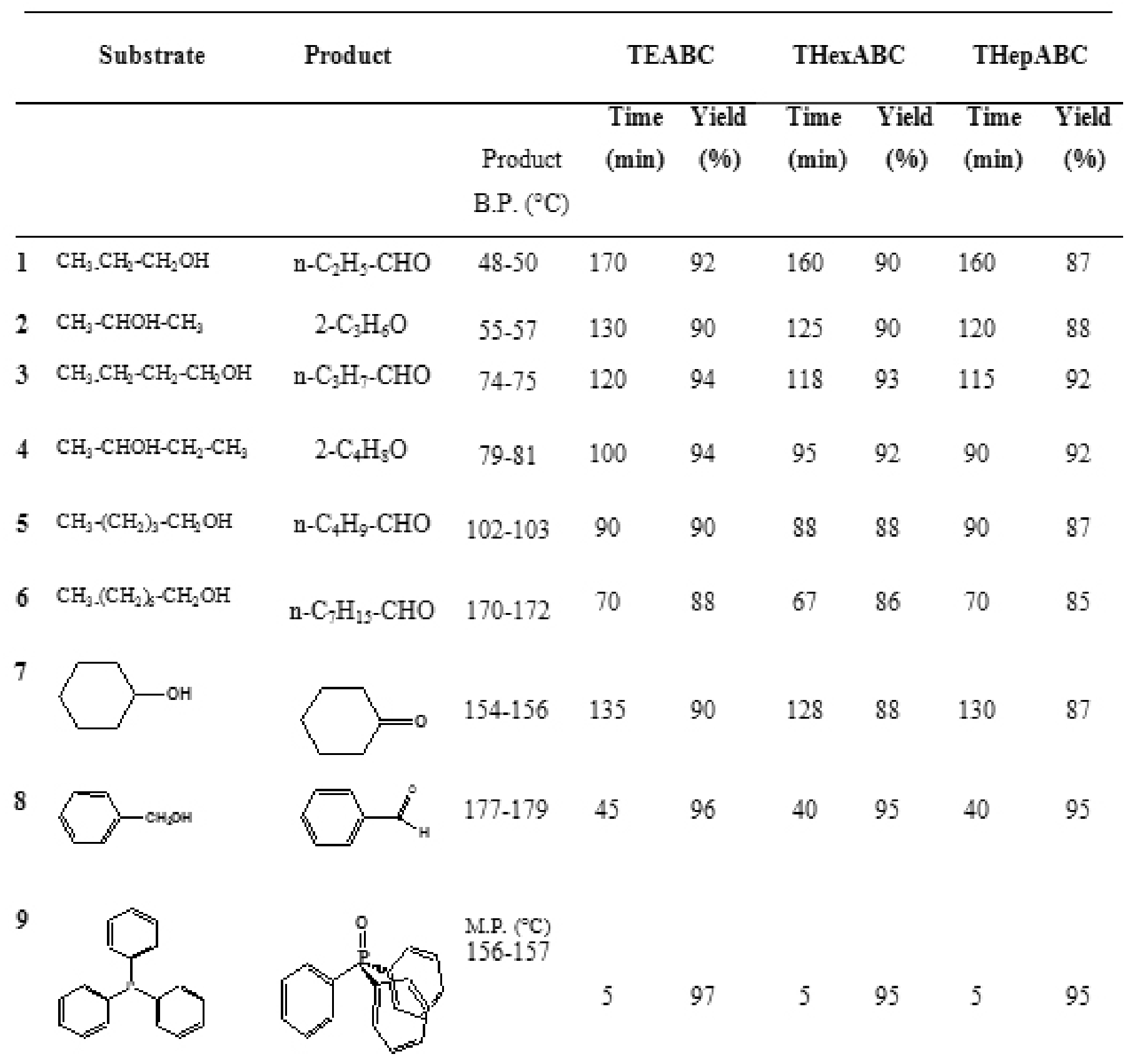


J. Chil. Chem. Soc., 54, No 4 (2009) 